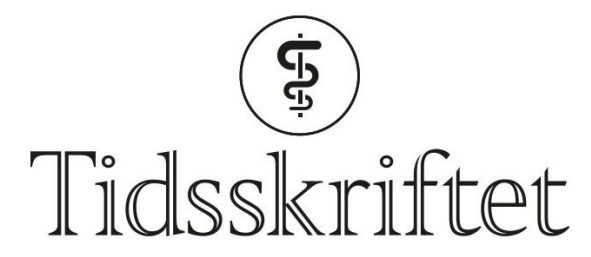

DEN NORSKE LEGEFORENING

\title{
Bedre forebygging av diabetisk nyresykdom
}

FRA ANDRE TIDSSKRIFTER

JON MAGNUS HAGA

Tidsskriftet

Tilleggsbehandling med liraglutid ved type 2-diabetes synes å redusere risikoen for nyresykdom.

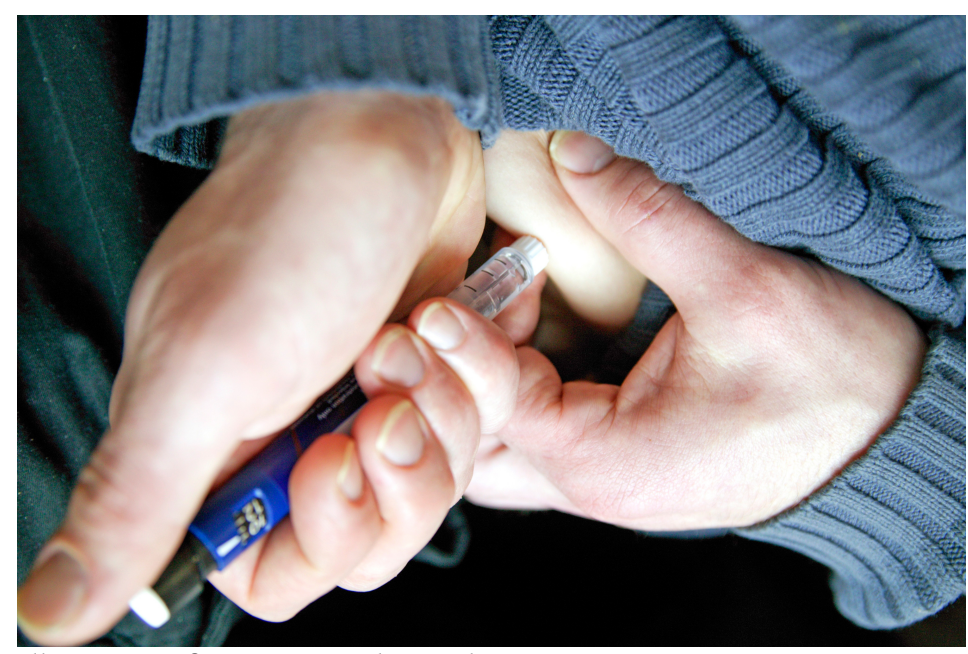

Illustrasjonsfoto: Science Photo Library

Type 2-diabetes er en vanlig årsak til nyresvikt. Det er vist at liraglutid, en glukagonlignende peptid-1-analog, har en gunstig effekt på blodsukkerkontroll og overlevelse ved diabetes. Kan midlet også gi redusert risiko for utvikling av nyresykdom?

I en nylig publisert studie ble om lag 10 ooo pasienter med type 2-diabetes randomisert til å motta vanlig diabetesbehandling med tillegg av liraglutid eller placebo og fulgt opp i 3,5-5 år (1). Som mål på nyresviktutvikling hadde forfatterne laget et skåringsverktøy som omfattet makroalbuminuri, serum-kreatininnivå, dialysebehov og nyrerelatert død. Liraglutidbehandling førte til en signifikant reduksjon i nyresviktutvikling (hasardratio o,78; $95 \% \mathrm{KI}$ o,67-0,92), og reduksjonen var særlig knyttet til lavere forekomst av makroalbuminuri.

- Denne studien er en fortsettelse av den internasjonale liraglutidstudien, der man tidligere har undersøkt effekten av liraglutid på kardiovaskulær sykdom, sier Tore Julsrud Berg, som er overlege og førsteamanuensis ved Avdeling for endokrinologi, sykelig overvekt og forebyggende medisin, Oslo universitetssykehus. 
- Effekten av tilleggsbehandling med liraglutid er tydelig, men ikke veldig stor - man må behandle 45 pasienter for å hindre at én pasient utvikler makroalbuminuri eller alvorligere nyresykdom, påpeker Berg.

- Med en marginal forskjell i glukosenivå mellom gruppene og en relativ kort oppfølgingsperiode er blodglukosefall neppe hele forklaringen, sier han.

\section{LITTERATUR:}

1. Mann JFE, Ørsted DD, Brown-Frandsen K et al. Liraglutide and renal outcomes in type 2 diabetes. $\mathrm{N}$ Engl J Med 2017;377: 839-48. [PubMed][CrossRef]

Publisert:30. oktober 2017. Tidsskr Nor Legeforen. DOI: 10.4045/tidsskr.17.0814

(C) Tidsskrift for Den norske legeforening 2020. Lastet ned fra tidsskriftet.no 